\title{
Treatment of diabetic vasculopathy: an overview
}

This article was published in the following Dove Press journal:

Research and Reports in Endocrine Disorders

5 December 201I

Number of times this article has been viewed

\section{Sayeeda Rahman' \\ Md Anwarul Azim \\ Majumder' \\ Abdul Rashid Abdul \\ Rahman $^{2}$ \\ 'Department of Clinical Sciences, School of Medical Sciences, University of Bradford, Bradford, UK; ${ }^{2}$ Cyberjaya University College of Medical Sciences, Cyberjaya, Malaysia}

Correspondence: Sayeeda Rahman Department of Clinical Sciences, School of Medical Sciences, University of Bradford, Bradford BD7 IDP, United Kingdom

Tel +44 I2 74236283

Email srahman6@bradford.ac.uk
Abstract: Type 2 diabetes is a chronic, degenerative, and noncommunicable disease, and is associated with a high prevalence of cardiovascular morbidity and mortality. The complications of diabetic vasculopathy are commonly grouped into microvascular and macrovascular complications. In diabetes, macrovascular complications are the commonest cause of morbidity and mortality and are responsible for a high incidence of vascular diseases. The aim of this review to provide an overview of current treatment modalities for diabetic vasculopathy and highlight the importance of effective control of blood glucose, blood lipids, and blood pressure, as well as reduction of blood hypercoagulability, in lowering the macrovascular complications of diabetic vasculopathy. A literature review was conducted to retrieve the relevant information using the PubMed, Science Direct, and Google Scholar databases, reports, and books. People with type 2 diabetes are at markedly increased risk for cardiovascular disease and mortality. The initiators of vasculopathy that ultimately develop into long-term diabetic complications can be avoided by a healthy lifestyle and pharmacological intervention. Clinical trials have shown that effective control of blood glucose, blood lipids, blood pressure, and blood hypercoagulability can reduce macrovascular complications in patients with type 2 diabetes. Type 2 diabetes is responsible for premature mortality, predominantly through atherosclerotic vascular disease. Lifestyle modification and pharmacotherapy should be used to prevent or delay development of type 2 diabetes, including adverse cardiovascular outcomes. A multidisciplinary approach involving patients, health professionals, and diabetic educators should be used to combat the type 2 diabetes epidemic and its associated cardiovascular complications.

Keywords: type 2 diabetes, diabetic vasculopathy, macrovasculopathy, cardiovascular disease

\section{Introduction}

Type 2 diabetes is a chronic, degenerative and noncommunicable disease, and is associated with a high prevalence of cardiovascular morbidity and mortality. The estimated prevalence of type 2 diabetes for 2010 has risen to 285 million from 151 million in 2000 , representing $6.6 \%$ of the world's adult population, and the total number of people with diabetes is projected to rise to 438 million in $2030 .{ }^{1}$ It is estimated that up to $80 \%$ of the 200 million people with diabetes globally will die of cardiovascular disease. ${ }^{2}$ Type 2 diabetes acts as an independent risk factor for several forms of cardiovascular disease, and people with type 2 diabetes are 2-4 times more likely to develop cardiovascular disease due to a variety of risk factors ${ }^{3}$ (Table 1). Studies have demonstrated that newly diagnosed, never-treated individuals with type 2 diabetes and no traditional cardiovascular risk factors develop early preclinical manifestations 
Table I Type 2 diabetes and cardiovascular disease

- Cardiovascular disease is a major complication and the leading cause of early death among people with T2DM; about $65 \%$ of people with T2DM die from heart disease and stroke"

- Adults with T2DM are 2-4 times more likely to have heart disease or suffer a stroke than people without T2DM"1

- High blood glucose in adults with T2DM increases the risk of heart attack, stroke, angina, and coronary artery disease ${ }^{12}$

- People with T2DM also have high rates of elevated blood pressure, lipid problems, and obesity, which contribute to their high rates of cardiovascular disease ${ }^{13}$

- T2DM is considered to be one of the six major controllable risk factors for cardiovascular disease. ${ }^{12}$

Abbreviation: T2DM, type 2 diabetes mellitus.

of macrovascular disease, ${ }^{4}$ and even normoglycemic and normotensive offspring of parents with type 2 diabetes ${ }^{5,6}$ and impaired glucose tolerance ${ }^{6}$ had early manifestations of preclinical vasculopathy and a potentially increased risk for development of macrovascular disease. ${ }^{6}$ Type 2 diabetes and its complications have a significant economic impact on individuals, families, health systems, and countries. ${ }^{7}$ People with type 2 diabetes who have complications cost health care systems 3.5 times more than people with no evidence of complications. ${ }^{8}$ It has been found that at least $10 \%$ of the total health budget is spent on the management of type 2 diabetes and its complications. ${ }^{9,10}$ According to World Health Organization estimates, China will lose $\$ 558$ billion in national income due to heart disease, stroke, and type 2 diabetes alone in the period 2006-2015. ${ }^{11}$ The initiators of vasculopathy that ultimately develop into long-term diabetic complications can be controlled and avoided by a healthy lifestyle and pharmacological intervention. This review examines the cardiovascular risk factors for type 2 diabetes, treatment modalities (lifestyle and pharmacological interventions), complications of diabetic vasculopathy, and the effects of effective control of blood glucose, blood lipids, blood pressure, and hypercoagulability in reduction of the macrovascular complications of diabetic vasculopathy.

A systematic review was conducted using the PubMed, Science Direct, and Google Scholar databases to identify the published literature on diabetic vasculopathy. Relevant reports and books were also consulted to retrieve appropriate information. For the database search, the following keywords were used: "type 2 diabetes", "diabetic vasculopathy", "macrovascular complications", "hyperglycemia", "hypertension", "dyslipidemia", and "hypercoagulability". The reference lists of the relevant papers were also screened, and only studies published in the English language were considered for review.

\section{Treatment modalities in diabetic vasculopathy}

Type 2 diabetes is a complex metabolic disorder characterized by persistent hyperglycemia in association with other cardiovascular risk factors. Important cardiovascular risk factors for diabetic vasculopathy include hyperglycemia, hypertension, hypercoagulability, and dyslipidemia, ie, high serum total cholesterol, elevated triglycerides, increased low-density lipoprotein (LDL) cholesterol, and decreased high-density lipoprotein (HDL) cholesterol.

Diabetic patients require therapy for each of these metabolic abnormalities to reduce atherogenesis and prevent cardiovascular complications. ${ }^{14}$ The main aims of treatment are to correct insulin resistance, beta cell dysfunction, and hepatic glucose output, as well as to prevent, delay, or reverse diabetic complications. The modalities of treatment currently available to manage type 2 diabetes include lifestyle modification (appropriate diet and exercise programs) and pharmacological intervention. Effective management of blood lipid, hypertension, blood glucose, and blood hypercoagulability can contribute to reduction of cardiovascular risk in people with type 2 diabetes.

\section{Lifestyle intervention}

Lifestyle management is recognized as being an essential part of management of type 2 diabetes and prevention of cardiovascular disease. Dietary restriction is recommended in type 2 diabetes to achieve weight loss and reduce the risk factors for cardiovascular disease. Weight loss lowers blood pressure and improves blood lipid concentrations, especially triglycerides and very low-density lipoprotein cholesterol. Exercise improves glycemic control, reduces certain cardiovascular risk factors, and increases psychological well being. ${ }^{15}$ Because obesity, hyperlipidemia, and hypertension are commonly associated with type 2 diabetes, treatment is frequently aimed at reversing all of these abnormalities by weight reduction via a combination of caloric restriction and increased energy expenditure through regular physical exercise. In addition, physical training in patients with type 2 diabetes has been shown to produce changes in insulin resistance, such as an increase in the number of skeletal muscle glucose transporters, which may reduce the need for hypoglycemic agents. ${ }^{16}$

\section{Pharmacotherapy}

In the majority of patients, type 2 diabetes is not well controlled by lifestyle modification, so presents major challenges for pharmacotherapy. ${ }^{17}$ The International 
Diabetes Federation global guidelines for type 2 diabetes recommend a glycosylated hemoglobin ( $\mathrm{HbA} 1 \mathrm{c})$ of $6.5 \%$ or lower to reduce the risk of complications. ${ }^{18}$ However, it was suggested to move the target to $8 \%$ in diabetic elders to simplify the diabetic regimen and to reduce the potential adverse effects of polypharmacy. ${ }^{19}$ An elevated $\mathrm{HbA} 1 \mathrm{c}$ level is considered to be an independent risk factor for coronary heart disease in people with and without diabetes. Selvin et $\mathrm{al}^{20}$ reported that a "high normal" HbA1c level predicts an elevated risk of coronary heart disease in persons without diabetes, and suggested an $\mathrm{HbA} 1 \mathrm{c} \geq 4.6 \%$ as a cut point for risk of future coronary heart disease events. Because these goals are rarely achieved through lifestyle modification alone, antidiabetic agents and other drugs are usually required to prevent complications related to diabetic vasculopathy. ${ }^{18}$ The major metabolic abnormalities and treatment modalities of diabetic vasculopathy are shown in Table 2.

\section{Treating hyperglycemia}

Patients with type 2 diabetes who are not successfully treated by diet are generally prescribed oral hypoglycemic drugs. These drugs help to promote a decrease in blood glucose, apparently by increasing the release of insulin from beta cells in the pancreas or by increasing the sensitivity of peripheral tissues to insulin, ${ }^{21-23}$ so are only effective in patients with some capacity for endogenous insulin production. The main group of hypoglycemic agents includes biguanides, sulfonylureas, alpha-glucosidase inhibitors, meglitinides, thiazolidinediones, incretin mimetics, dipeptidyl peptidase- 4 (DPP-4) inhibitors, and insulin.

Sulfonylureas work by stimulating insulin release from the pancreas and may slightly improve insulin resistance in peripheral target tissues. Sulfonylureas reduces $\mathrm{HbA} 1 \mathrm{c}$ levels by $0.8 \%-2.0 \%$ and fasting plasma glucose concentrations by 3.3-3.9 mmol/L. ${ }^{24-26}$ Nonsulfonylurea insulin secretagogue agents, eg, meglitinides (repaglinide, nateglinide), have a very short onset (15-30 minutes) of action and a short metabolic half-life (1-1.5 hours). ${ }^{27}$

Metformin is the most commonly used biguanide. It is suggested as the first-line drug of choice for the treatment of type 2 diabetes, particularly in overweight and obese people and those with normal kidney function. ${ }^{28}$ The major action of metformin in patients with type 2 diabetes is to reduce hepatic glucose output, primarily by decreasing gluconeogenesis, and to a lesser extent, by enhancing insulin sensitivity in hepatic and peripheral tissues. In placebo-controlled trials, metformin reduced $\mathrm{HbA} 1 \mathrm{c}$ levels by approximately $1.0 \%-2.0 \% .^{25,29,30}$
Other effects include a reduction in plasma triglyceride levels and LDL cholesterol levels.

The thiazolidinediones (eg, rosiglitazone and pioglitazone) work by enhancing insulin sensitivity in both muscle and adipose tissue, and to a lesser extent, by inhibiting hepatic glucose production. These agents achieve notable improvement in insulin resistance, particularly when used in combination with other antidiabetic drugs, but have no effect on insulin secretion. As a class, the thiazolidinediones have also been shown to alter the lipid profile in patients with type 2 diabetes. These drugs have potentially favorable effects on other components of the insulin resistance syndrome. As insulin sensitizers, they may modify cardiovascular risk factors and reduce cardiovascular mortality in type 2 diabetes and subjects with insulin resistance. ${ }^{31,32}$ However, there is a growing recognition that edema and weight gain can occur in patients treated with rosiglitazone and pioglitazone. Because people with diabetes are at increased risk of cardiovascular disease and many have pre-existing heart disease, the edema and weight gain may lead to congestive heart failure. ${ }^{33} \mathrm{~A}$ meta-analysis of 42 clinical trials concluded that rosiglitazone was associated with an increased risk of myocardial infarction and cardiovascular death compared with nonthiazolidinedione therapies, ${ }^{34}$ whereas another review of 19 trials of pioglitazone demonstrated reduction in nonfatal acute myocardial infarction, stroke, and all-cause mortality. ${ }^{35}$ These findings were also supported by a recent study in Medicare beneficiaries in the US, which found that rosiglitazone was associated with an increased risk of stroke, heart failure, and death when compared with pioglitazone. ${ }^{36}$ However, the interim US Food and Drug Administration review of an ongoing epidemiological study warned that use of pioglitazone for more than one year may be associated with an increased risk of bladder cancer. ${ }^{37}$

Alpha-glucosidase inhibitors (ie, acarbose, miglitol, voglibose) delay the absorbance of carbohydrates in the gut by inhibiting the alpha-glucosidase enzyme found in the brush border cells that line the small intestine. These enzymes are essential for the release of glucose from more complex carbohydrates. ${ }^{38}$ Because they inhibit the breakdown and subsequent absorption of carbohydrates (dextrins, maltose, sucrose and starch; no effect on glucose) from the gut following meals, the biggest impact of these drugs is on postprandial hyperglycemia. They have been associated with a reduction in $\mathrm{HbA} 1 \mathrm{c}$ of $0.7 \%-1.0 \%$ and fasting plasma glucose levels by $1.9-2.2 \mathrm{mmol} / \mathrm{L} .{ }^{24,25,39,40}$

A recent advance in the management of type 2 diabetes has been the development and clinical use of 
Table 2 Treatment modalities for diabetic vasculopathy

\begin{tabular}{|c|c|c|c|}
\hline \multirow[t]{8}{*}{$\begin{array}{l}\text { Hyperglycemia } \\
\text { Insulin resistance }\end{array}$} & Biguanides & $\begin{array}{l}\text { Increase liver and muscle insulin sensitivity; } \\
\text { decreases hepatic glucose production }\end{array}$ & $\begin{array}{l}\text { Temporary nausea, loss of appetite, diarrhea, } \\
\text { increased abdominal gas, metallic taste }\end{array}$ \\
\hline & Sulfonylureas & $\begin{array}{l}\text { Insulin secretagogues, bind to sulfonylurea } \\
\text { receptor I, cause depolarization and calcium influx, } \\
\text { initiate insulin secretion }\end{array}$ & $\begin{array}{l}\text { Hypoglycemia, weight gain, skin reaction, dark } \\
\text { urine, stomach upset, increased sensitivity } \\
\text { to sun }\end{array}$ \\
\hline & $\begin{array}{l}\alpha \text {-glucosidase } \\
\text { inhibitors }\end{array}$ & $\begin{array}{l}\text { Delay absorption of polysaccharides and act } \\
\text { to attenuate postprandial glucose excursions }\end{array}$ & $\begin{array}{l}\text { Slight weight gain, gastrointestinal } \\
\text { disturbances, ie, abdominal bloating, } \\
\text { flatulence, diarrhea }\end{array}$ \\
\hline & $\begin{array}{l}\text { Sulfonylurea-like } \\
\text { agents }\end{array}$ & $\begin{array}{l}\text { Insulin secretagogues, bind to sulfonylurea } \\
\text { receptor I at a different site to sulfonylureas, } \\
\text { resulting in rapid and shorter insulin response }\end{array}$ & Weight gain, hypoglycemia \\
\hline & Thiazolidinediones & $\begin{array}{l}\text { Insulin sensitizers that improve glucose uptake } \\
\text { in adipose tissues and skeletal muscles }\end{array}$ & $\begin{array}{l}\text { Fluid retention, decreased hemoglobin, } \\
\text { congestive heart failure, fractures }\end{array}$ \\
\hline & $\begin{array}{l}\text { Glucagon-like } \\
\text { peptide-I mimetics }\end{array}$ & $\begin{array}{l}\text { Bind to glucagon-like peptide-I receptor, increase } \\
\text { glucose-dependent insulin secretion and glucagon } \\
\text { suppression }\end{array}$ & $\begin{array}{l}\text { Gastrointestinal side effects, avoid in renal } \\
\text { failure }\end{array}$ \\
\hline & $\begin{array}{l}\text { Dipeptidyl- } \\
\text { peptidase-4 inhibitors }\end{array}$ & $\begin{array}{l}\text { Prolong and enhance the activity of endogenous } \\
\text { glucagon-like-peptide-I and glucose-dependent } \\
\text { insulinotropic polypeptide, serve as prandial } \\
\text { stimulators of insulin secretion and regulate } \\
\text { glycemia }\end{array}$ & Unconfirmed association with pancreatitis \\
\hline & Insulin & $\begin{array}{l}\text { Reduces hepatic glucose output and increases } \\
\text { peripheral glucose utilization }\end{array}$ & $\begin{array}{l}\text { Hypoglycemia, weight gain, skin rashes, } \\
\text { shortness of breath, swelling of face }\end{array}$ \\
\hline \multirow[t]{5}{*}{ Hypertension } & ACE inhibitors & $\begin{array}{l}\text { Block formation of AT-II, increase bradykinin level; } \\
\text { as a result, reduce vasoconstriction, reduce sodium } \\
\text { and water retention, and increase vasodilation } \\
\text { (through bradykinin) }\end{array}$ & $\begin{array}{l}\text { Long-lasting dry cough, skin rash, swelling } \\
\text { of your sinuses, sore throat, elevated blood } \\
\text { potassium level, feeling sick or vomiting, } \\
\text { indigestion, diarrhea, or constipation }\end{array}$ \\
\hline & $\begin{array}{l}\text { Angiotensin receptor } \\
\text { blockers }\end{array}$ & $\begin{array}{l}\text { Competitive inhibition of AT-II receptor (type I); } \\
\text { effect more specific on AT-II action, less or none } \\
\text { on bradykinin production or metabolism }\end{array}$ & $\begin{array}{l}\text { Hyperkalemia, dizziness, headache, } \\
\text { drowsiness, diarrhea, metallic taste, rash }\end{array}$ \\
\hline & Beta-blockers & $\begin{array}{l}\text { Inhibit renin release and AT-II and aldosterone } \\
\text { production and lower peripheral resistance; may } \\
\text { decrease adrenergic outflow from the central } \\
\text { nervous system }\end{array}$ & $\begin{array}{l}\text { Dizziness, lightheadedness, drowsiness } \\
\text { and blurred vision }\end{array}$ \\
\hline & $\begin{array}{l}\text { Calcium channel } \\
\text { blockers }\end{array}$ & $\begin{array}{l}\text { Dilate peripheral arterioles and thereby reduce } \\
\text { BP by inhibiting calcium influx into arterial smooth } \\
\text { muscle cells }\end{array}$ & $\begin{array}{l}\text { Constipation, feeling sick, palpitations, } \\
\text { tiredness, dizziness, and rashes }\end{array}$ \\
\hline & Diuretics & $\begin{array}{l}\text { Lower BP by depleting body sodium stores, } \\
\text { resulting in reduction of total blood volume } \\
\text { and cardiac output; initially peripheral vascular } \\
\text { resistance increases but declines when cardiac } \\
\text { output returns to normal level (6-8 weeks) }\end{array}$ & $\begin{array}{l}\text { Increased urination, low sodium in your blood } \\
\text { (hyponatremia), increased blood sugar, and } \\
\text { increased cholesterol }\end{array}$ \\
\hline \multirow[t]{2}{*}{ Dyslipidemia } & Statins & $\begin{array}{l}\text { Increase lipid profile and decrease atherogenic } \\
\text { tendency; lower LDL-C, improve TC to } \\
\text { HDL-C ratio, lower apo B }\end{array}$ & $\begin{array}{l}\text { Migraine headaches, pain and weakness } \\
\text { of muscles, drowsiness, dizziness, constipation }\end{array}$ \\
\hline & $\begin{array}{l}\text { Fibric acid } \\
\text { derivatives }\end{array}$ & $\begin{array}{l}\text { Increase lipid profile and decrease atherogenic } \\
\text { tendency; lower triglycerides, raise HDL-C, lower } \\
\text { TC to HDL-C ratio and shift LDL from smaller } \\
\text { to larger particles }\end{array}$ & $\begin{array}{l}\text { Abdominal pain, constipation, diarrhoea, } \\
\text { nausea, headache, fatigue, dizziness, muscle } \\
\text { tenderness or soreness }\end{array}$ \\
\hline \multirow[t]{3}{*}{$\begin{array}{l}\text { Platelet activation } \\
\text { and aggregation }\end{array}$} & Aspirin & Antiplatelet effect & $\begin{array}{l}\text { Irritation of the stomach or bowel, } \\
\text { indigestion, nausea, dizziness, ringing } \\
\text { in the ears, vomiting }\end{array}$ \\
\hline & Clopidogrel & $\begin{array}{l}\text { Irreversible blockade of the adenosine diphosphate } \\
\text { receptor on platelet cell membranes }\end{array}$ & $\begin{array}{l}\text { Bleeding/bruising, stomach upset/pain, } \\
\text { diarrhea/constipation }\end{array}$ \\
\hline & Ticlopidine & Interferes with platelet membrane function & $\begin{array}{l}\text { Allergic reaction, difficult breathing, swelling } \\
\text { of face, lip, tongue/throat }\end{array}$ \\
\hline
\end{tabular}

Abbreviations: ACE, angiotensin-converting enzyme; BP, blood pressure; LDL-C, low-density lipoprotein cholesterol; HDL-C, high-density lipoprotein cholesterol; TC, total cholesterol; apo B, apolipoprotein B; AT-II, angiotensin II. 
incretin-based therapies, ie, glucagon-like peptide-1 (GLP-1) receptor analogs (eg, exenatide) and DPP-4 inhibitors (eg, sitagliptin, vildagliptin, saxagliptin). ${ }^{41-44}$ The former are given subcutaneously while the latter are taken orally. GLP-1 receptor agonists mimic the action of GLP-1 and increase the incretin effect in patients with type 2 diabetes, stimulating the release of insulin. These drugs help in preservation of beta cell mass and function, do not produce hypoglycemia, help in weight reduction, and are associated with significant reductions in $\mathrm{HbA} 1 \mathrm{c}$ of $1 \% .{ }^{41} \mathrm{DPP}-4$ inhibitors prevent degradation of endogenous GLP-1 and glucose-dependent insulinotropic polypeptide, thereby helping in glycemic control, and are associated with reductions in $\mathrm{HbA} 1 \mathrm{c}$ of $0.6 \%-0.7 \%$, with no weight gain and a low risk of hypoglycemia. ${ }^{42}$

\section{Treating hypertension}

The coexistence of hypertension in patients with type 2 diabetes is particularly destructive because of the strong linkage between both these two conditions and macrovascular complications. ${ }^{45}$ Hypertension is present at the time of diagnosis of type 2 diabetes in over one-third of patients, often coexisting with dyslipidemia, central obesity, and increased susceptibility to cardiovascular disease. ${ }^{46}$ The guidelines put out by the $\mathrm{JNC}^{45}$ and American Diabetes Association ${ }^{47}$ recommend control of blood pressure in patients with type 2 diabetes to levels of $130 / 80 \mathrm{mmHg}$ or lower. These guidelines also recommend lifestyle modifications, such as smoking cessation, avoidance of excess alcohol, and exercise. Studies of hypertension control in type 2 diabetes show that effective control of blood pressure leads to substantially reduced risk of cardiovascular events and death. ${ }^{48-52}$

Regarding the selection of medications, the evidence shows that diuretics, angiotensin-converting enzyme (ACE) inhibitors, beta-blockers, angiotensin II receptor blockers, and calcium antagonists have a benefit in the treatment of hypertension and that the majority of patients with type 2 diabetes require two or more drugs to achieve blood pressure control. Thiazide diuretics are found to be beneficial in type 2 diabetes, either alone or as part of a combined regimen. ${ }^{45}$ ACE inhibitors reduce macrovascular complications in type 2 diabetes, appear to improve insulin sensitivity and glucose metabolism, ${ }^{31,53}$ and can be used alone, but are found to be much more effective when combined with a thiazide diuretic or other antihypertensive drugs. ${ }^{45}$ Beta-blockers, especially beta 1-selective agents, are beneficial in type 2 diabetes as part of multidrug therapy, but their value as monotherapy is less clear. ${ }^{45}$ Angiotensin II receptor blockers also show protective cardiovascular effects similar to those of ACE inhibitors, particularly in type 2 diabetic patients after myocardial infarction and in those with heart failure. ${ }^{54}$ Although beta-blockers are indicated in type 2 diabetic patients with ischemic heart disease, they are found to be less effective than angiotensin II receptor blockers in preventing stroke. ${ }^{55}$ Calcium antagonists may be useful to control blood pressure in type 2 diabetes, particularly as part of combination therapy. ${ }^{45}$ Patients taking treatment for high blood pressure based on a calcium channel blocker have a lower risk of developing type 2 diabetes and associated complications than patients using a beta-blocker. ${ }^{56}$

\section{Treating dyslipidemia}

Dyslipidemia is strongly correlated with insulin resistance and hyperinsulinemia. ${ }^{17}$ It is present at the time of diagnosis as a part of the insulin resistance syndrome and persists despite treatment of glycemia. Lipid-lowering agents reduce the risk of major macrovascular events in patients with type 2 diabetes. ${ }^{57,58}$ Statins (HMG-CoA reductase inhibitors) are considered to be first-line therapy for the majority of type 2 diabetic patients. ${ }^{17}$ Treating dyslipidemia in type 2 diabetes with statins has demonstrated benefit in both the primary and secondary prevention of cardiovascular disease. ${ }^{57,59,60}$ Several studies have also shown benefits associated with fibrate treatment. ${ }^{61-63}$ Statins lower LDL-C, improve the total cholesterol to HDL-C ratio, and lower apolipoprotein $\mathrm{B}$, while fibrates lower triglycerides, raise HDL-C, lower the total cholesterol to HDL-C ratio, and shift LDL from smaller to larger particles. ${ }^{31}$ Recent evidence suggests that use of moderate to high doses of statins increases the risk of developing new-onset diabetes, ${ }^{64,65}$ and it has been advised to exercise caution in using statins for patients with cardiovascular risk or where cardiovascular benefit has not been proven. ${ }^{64}$

\section{Treating hypercoagulability}

Patients with type 2 diabetes have heightened platelet activity, which increases their risk of cardiovascular events. ${ }^{66}$ Aspirin, clopidogrel, dipyridamole, and the glycoprotein $\mathrm{IIb} / \mathrm{III}$ a receptor antagonists reduce cardiovascular risk in patients with type 2 diabetes $^{17}$ due to their antiplatelet effects. A considerable body of evidence has accumulated about the benefits of antiplatelet therapy, in most cases for aspirin, in patients with a previous cardiovascular event. ${ }^{17}$ Aspirin irreversibly inhibits prostaglandin $\mathrm{H}$ synthase (cyclo-oxygenase-1) in platelets and megakaryocytes, and 
thereby blocks the formation of thromboxane A2, a potent vasoconstrictor and platelet aggregant. ${ }^{67}$ The thienopyridine derivatives (clopidogrel, ticlopidine) are metabolized in the liver to active compounds which covalently bind to the adenosine phosphate receptor on platelets and dramatically reduce platelet activation. Dipyridamole inhibits phosphodiesterase, which inactivates cyclic adenosine monophosphate. Increased intraplatelet concentrations of cyclic adenosine monophosphate reduce the activation of cytoplasmic second messengers. Dipyridamole also stimulates prostacyclin release and inhibits thromboxane A2 formation. Glycoprotein $\mathrm{IIb} / \mathrm{III}$ a receptor antagonists block the final common pathway for platelet aggregation.

\section{Clinical trials on prevention and treatment of diabetic vasculopathy Lifestyle intervention}

Increased rates of obesity and decreased physical activity are strongly linked with an increased prevalence and incidence of type 2 diabetes. ${ }^{68}$ Obesity is a predictor of both coronary heart disease and type 2 diabetes, and about $80 \%-90 \%$ of type 2 diabetes is attributable to excess weight. ${ }^{69}$ Obesity adversely affects blood pressure and plasma lipid levels, and even moderate weight loss can improve glycemic control, insulin sensitivity, blood pressure, and lipid profiles in obese patients with type 2 diabetes, at least in the short term. ${ }^{69-73}$ Diet can be used to achieve or maintain a healthy weight and to achieve target metabolic outcomes, including improved plasma glucose and lipid levels, as well as lowering of elevated blood pressure. ${ }^{73}$ Patients with type 2 diabetes are encouraged to eat carbohydrates in the form of whole grains, fruit, vegetables, and low-fat dairy products, to use sweeteners in place of other carbohydrates in the diet, and to reduce intake of saturated fats. ${ }^{71}$ Exercise directly improves insulin sensitivity, glycemic control, plasma lipid levels, blood pressure, and body weight, and decreases adverse cardiovascular events. ${ }^{74}$ Exercise can also affect these factors indirectly by decreasing plasma insulin levels. ${ }^{75}$ The majority of the studies focusing on diabetes prevention have not been long enough to assess cardiovascular outcomes. ${ }^{76}$ Moreover, the original designs of these studies were not intended to examine cardiovascular outcomes, which restricted the statistical analysis to detecting reductions in the incidence of cardiovascular and mortality risk. ${ }^{76}$ Because there are no complete studies assessing the effect of intensive lifestyle intervention on cardiovascular outcome in type 2 diabetes, further follow-up of ongoing trials is necessary to acquire evidence-based information. ${ }^{76}$
A multicenter, randomized controlled trial known as Look AHEAD (Action for Health in Diabetes) enrolled 5145 obese patients with type 2 diabetes for an estimated period of 10 years to evaluate if an average weight loss of $7 \%$ body weight by altered diet and exercise habit reduces the risk of cardiovascular disease. ${ }^{77}$ The one-year results of Look AHEAD demonstrate that intensive lifestyle intervention results in clinically significant weight loss in people with type 2 diabetes which is associated with improved diabetes control and cardiovascular risk factors and, at the same time, reduced medication use and cost. ${ }^{78}$ Several further years are needed to determine whether the initial weight loss can be maintained, whether intentional weight loss has a long-term effect on risk factors, and whether the weight loss reduces cardiovascular mortality and morbidity. ${ }^{78,79} \mathrm{Li}$ et al reported 20-year follow-up results on incidence of type 2 diabetes and cardiovascular disease from the China Da Qing Diabetes Prevention Study ${ }^{80}$ and found that the reduction in diabetes incidence persists in the combined intervention group, which is also supported by the findings from the Finnish Diabetes Prevention Study ${ }^{81}$ (with seven years of follow-up). However, whether lifestyle intervention also leads to reduced cardiovascular disease and mortality remains unclear.

A meta-analysis demonstrated that lifestyle intervention (diet and physical activity) led to a $63 \%$ reduction in the incidence of type 2 diabetes in high-risk groups. ${ }^{76}$ This analysis included intensive lifestyle intervention studies ${ }^{82-87}$ which showed that there were reductions in cardiovascular risk factors in patients with type 2 diabetes, impaired glucose tolerance, and impaired fasting glycemia, and in obese individuals with and without the metabolic syndrome. However, evidence for the effect of lifestyle intervention on clinical cardiovascular outcomes was lacking. Another review ${ }^{88}$ conducted by Orozco et al, which included eight trials, ${ }^{83,86,87,89-93}$ had an exercise plus diet arm (2241 participants) and a standard recommendation arm (2509 participants), with a study duration of 1-6 years. The analysis found that the incidence of type 2 diabetes was reduced by $37 \%$ (relative risk reduction) with exercise and diet, but no study reported relevant data on type 2 diabetes and cardiovascular disease-related morbidity, all-cause mortality, and quality of life. The investigators recommended that there is a need for studies to explore the effect of exercise and diet on quality of life, morbidity, and mortality, with a special focus on cardiovascular outcomes.

\section{Glycemia control}

Prolonged hyperglycemia is now recognized as a major factor in the pathogenesis of diabetic vasculopathy. ${ }^{31}$ Positive 
correlations between measures of glycemic control and cardiovascular outcomes were also identified by several observational studies. ${ }^{94-96}$ Results from clinical trials examining the effect of intensive glucose control on cardiovascular disease have failed to show consistent beneficial effects on cardiovascular events. ${ }^{97-100}$ It was demonstrated that intensive glucose control reduces the risk of microvascular complications among patients with type 2 diabetes, but its effect on cardiovascular disease is uncertain. ${ }^{49,101,102}$ Early data from UKPDS (the United Kingdom Prospective Diabetes Study) 34 suggested a protective effect of improved glucose control on cardiovascular disease, cardiovascular mortality, and all-cause mortality. ${ }^{97}$ However, a number of large randomized, controlled trials ${ }^{98,100,103-105}$ have reported conflicting results. In three published trials, ie, ADVANCE (Action in Diabetes and Vascular Disease: Preterax and Diamicron Modified Release Controlled Evaluation) ${ }^{98}$ VADT (Veterans Affairs Diabetes Trial), ${ }^{103}$ and NAVIGATOR (Nateglinide and Valsartan in Impaired Glucose Tolerance Outcomes Research), ${ }^{104}$ no effect of intensive glucose control on major cardiovascular events was reported. However, ACCORD (Action to Control Cardiovascular Disease in Diabetes) ${ }^{100}$ demonstrated an increased risk of death from cardiovascular causes and total mortality associated with intensive glucose control. In the PROactive (Prospective Pioglitazone Clinical Trial in Macrovascular Events) study, ${ }^{106}$ patients treated with pioglitazone had a significant $16 \%$ reduction in mortality, nonfatal myocardial infarction, and stroke.

A meta-analysis, which enrolled 33,040 participants, measured the effect of intensive glucose-lowering treatment on cardiovascular outcomes and death in patients with type 2 diabetes, ${ }^{107}$ and analyzed five randomized, controlled trials (ie, UKPDS, ${ }^{49,97}$ ADVANCE, ${ }^{98}$ VADT,${ }^{103,108}$ ACCORD, ${ }^{100}$ and PROactive $\left.^{105-106,109}\right)$. This review demonstrated that intensive glucose control has cardiovascular benefit compared with standard treatment for individuals with type 2 diabetes and a significant $17 \%$ reduction in nonfatal myocardial infarction events and a significant $15 \%$ reduction in coronary heart disease events.

Marso et al ${ }^{110}$ performed a meta-analysis of six studies $49,97,98,100,103,111$ (four randomized, controlled trials; 27,544 patients; mean follow-up 5.4 years; duration 1990-2009) evaluating the effect of intensive glucose control on major adverse cardiovascular events (ie, all-cause mortality, nonfatal myocardial infarction, and nonfatal stroke) in patients with type 2 diabetes. The review failed to establish any effect on mortality from cardiovascular or any cause or nonfatal stroke, but did find a significant
$14 \%$ reduction in nonfatal myocardial infarction in patients randomized to intensive glucose control. Another systematic review $^{112}$ of five trials (1950-2009) ${ }^{49,97,98,100,103}$ conducted by Kelly et al involving 27,802 adults found that intensive glucose control reduced the risk for some cardiovascular outcomes, but did not reduce the risk of cardiovascular death or all-cause mortality. Coutinho et $\mathrm{al}^{113}$ conducted a meta-regression analysis of published data (1966-1996) from 20 studies $^{114-134}$ of 95,783 individuals followed for 12.4 years and demonstrated a progressive relationship between glucose levels and cardiovascular risk extending even below the diabetic threshold. A recent meta-analysis demonstrated a modest (9\%) but statistically significant reduction in cardiovascular disease outcomes, including nonfatal myocardial infarction, and no increase in mortality. ${ }^{135}$ In light of these study results, it is apparent that further research is needed to examine pharmacological approaches for the management of hyperglycemia which also affect cardiovascular disease risk reduction.

\section{Blood pressure control}

Patients with type 2 diabetes and hypertension are always at increased risk of morbidity and mortality from cardiovascular events. Diabetic vasculopathy can be improved by lowering blood pressure with antihypertensive drugs which have antiatherogenic effects, eg, ACE inhibitors, angiotensin II receptor blockers, beta-blockers, and calcium channel blockers. Randomized controlled trials that have involved large numbers of hypertensive diabetic patients, eg, UKPDS $38,{ }^{50}$ the HOT (Hypertension Optimal Treatment) trial, ${ }^{48}$ SHEP (the Systolic Hypertension in the Elderly Program), ${ }^{136-138}$ the Syst-EUR (Systolic Hypertension in Europe) trial, ${ }^{137-139}$ the HOPE (Heart Outcomes Prevention Evaluation), study ${ }^{140}$ the LIFE (Losartan Intervention For Endpoint Reduction in Hypertension) study,${ }^{141}$ and ALLHAT (the Anti-hypertensive and Lipid-Lowering Treatment to Prevent Heart Attack Trial), ${ }^{142}$ have revealed that adequate blood pressure control improves cardiovascular outcomes, especially for stroke, when aggressive blood pressure targets are met. ${ }^{48,50,143,144}$

The UKPDS investigation of hypertension demonstrated that a $10 \mathrm{mmHg}$ reduction in mean systolic blood pressure (SBP) led to a $44 \%$ reduction in stroke incidence, with more than $20 \%$ of patients requiring three or more drugs to achieve target blood pressure.$^{50}$ It was found that in the tight control group $(150 / 85 \mathrm{mmHg})$, there were substantial reductions in risk for any type 2 diabetes endpoint, deaths related to type 2 diabetes, and stroke, but a nonsignificant change in all-cause mortality. In another landmark trial, ie, the HOT 
study, patients with type 2 diabetes randomly assigned to a diastolic blood pressure (DBP) target of $80 \mathrm{mmHg}$ had a significantly reduced risk of cardiovascular death and major cardiovascular events, and a nonsignificant trend toward improved overall mortality compared with those who had a target DBP of $90 \mathrm{mmHg} .{ }^{48}$ The study supports a lower DBP target in order to reduce stroke events in patients with diabetes. In the Syst-EUR trial, ${ }^{51}$ mean decreases in SBP $(8.6 \mathrm{mmHg})$ and DBP $(3.9 \mathrm{mmHg})$ in type 2 diabetic patients led to improvement in risk of cardiovascular death, all cardiovascular events, and stroke. In the ADVANCE study, ${ }^{98}$ blood pressure was lowered to $135 / 78 \mathrm{mmHg}$ with positive effects, but the ACCORD study ${ }^{100}$ did not find any benefit from lowering blood pressure below 120/80 $\mathrm{mmHg}$.

In the Micro-HOPE (Micro-Heart Outcomes Prevention Evaluation) study, the cardiovascular effects of ramipril (an ACE inhibitor) were evaluated in patients with type 2 diabetes. ${ }^{140,145}$ The drug showed significantly lower risks for cardiovascular outcomes, total mortality, and microvascular diabetes complications. The Micro-HOPE study ${ }^{140}$ showed that ramipril reduced the risks of stroke by $33 \%$ in patients with type 2 diabetes and this treatment was also associated with a significant $34 \%$ reduction in new diagnosis of type 2 diabetes cases. The evidence suggests that angiotensin II receptor blockers have cardiovascular protective effects similar to those of ACE inhibitors, particularly in post-myocardial infarction patients and in those with heart failure. ${ }^{54}$ ONTARGET (Ongoing Telmisartan Alone and in Combination with Ramipril Global Endpoint trial) is the first trial to demonstrate that telmisartan (an angiotensin II receptor blocker) is as effective as ramipril for cardiovascular protection in a high-risk, ACE-tolerant population. ${ }^{146}$

Clinical trials have impressively shown that treatment with conventional antihypertensive agents, including cardioselective beta-blockers, reduces morbidity and mortality in patients with systolic and diastolic hypertension. ${ }^{147}$ The subanalysis of the CAPPP (Captopril Prevention Project) hypertension study compared captopril (an ACE inhibitor) with conventional antihypertensive treatment based on betablockers and diuretics. ${ }^{148}$ The prospective evaluation of this study demonstrated that captopril is superior to conventional therapy in preventing cardiovascular events in hypertensive type 2 diabetic patients, especially in those with metabolic decompensation. The UKPDS ${ }^{50}$ in type 2 diabetes with hypertension showed first-line beta-blockade to be at least as effective as ACE inhibition in preventing all primary macrovascular endpoints. In the UKPDS, atenolol was found to be as effective as captopril in reducing cardiovascular events and stroke, despite equivalent blood pressure, at baseline and after nine years of follow-up. ${ }^{50}$ Conversely, the LIFE study comparing losartan and atenolol showed a $39 \%$ reduction in all-cause mortality in favor of losartan in a diabetic subgroup. ${ }^{55}$ Stroke incidence in the ALLHAT study was $15 \%$ higher with lisinopril (an ACE inhibitor) than with a thiazide diuretic. ${ }^{142}$ The substudy of ASCOT (Anglo-Scandinavian Cardiac Outcomes Trial) reported that calcium channel blockers and ACE inhibitors may prevent progression of atherosclerosis in diabetic patients better than beta-blocker-based and diuretic-based regimens. ${ }^{149}$

A comparative analysis ${ }^{150}$ was performed using eight trials ( $\mathrm{n}=130,270 ; 1996-2007)$ to analyze the effects of beta-blockers on cardiovascular outcomes in type 2 diabetic patients with hypertension. Myocardial infarction, stroke, cardiovascular mortality, and total mortality were the outcomes analyzed. The analysis found that beta-blockers have an increased risk of cardiovascular mortality when compared with renin-angiotensin system blockers in type 2 diabetic patients with hypertension. However, beta-blockers do not carry an increased risk for myocardial infarction, stroke, cardiovascular mortality, and total mortality when compared with control antihypertensive therapy in type 2 diabetic patients with hypertension.

Grossman and Messerli ${ }^{151}$ examined 14 studies $^{48,51,52,55}$, $142,148,152-161$ to assess the effects of calcium antagonists in hypertensive patients with type 2 diabetes. When compared with conventional therapy, it was found that calcium antagonists had similar effects on coronary heart disease and total mortality, but may have reduced the risk of stroke. The analysis concluded that calcium antagonists are safe and effective for reducing most types of cardiovascular morbidity and mortality in type 2 diabetic patients with hypertension, although their use is associated with a lesser reduction of risk of heart failure than other treatments for hypertension.

Another review ${ }^{162}$ of hypertension control in type 2 diabetes showed a clear and consistent effect of improved blood pressure control, ie, a substantially reduced risk of cardiovascular events and death. ${ }^{48,50-52,163-165}$ Treatment of hypertension in type 2 diabetic patients with a blood pressure goal of 135/80 mmHg demonstrated dramatic benefits. Thiazide diuretics, angiotensin II receptor blockers, and ACE inhibitors may be the best first-line treatments, although other agents are usually necessary, and goals may not be achieved even with three or four agents. It was also advised that aggressive blood pressure control may be the most important factor in preventing adverse outcomes in patients with type 2 diabetes. 


\section{Maintaining normal lipid profiles}

Dyslipidemia contributes substantially to cardiovascular complications in patients with type 2 diabetes. Diabetic dyslipidemia comprises elevated total cholesterol and LDL cholesterol, decreased HDL cholesterol, and high triglyceride levels. ${ }^{166,167}$ Studies have shown that lowering LDL cholesterol reduces the risk of major vascular events in a wide range of high-risk participants, including type 2 diabetics. ${ }^{168}$ Randomized clinical trials in type 2 diabetes have consistently shown that statins significantly reduce the risk of major primary and secondary cardiovascular disease endpoints. Clinical trials of fibrate therapy have shown mixed results. A meta-analysis of data from 10 controlled trials ${ }^{169-178}$ in a range of people with cardiovascular risk factors, including type 2 diabetes, found that primary prevention with statins had similar relative effects on cardiovascular risk as secondary prevention. ${ }^{179}$ Evidence has gradually accrued on the benefit of statins in preventing cardiovascular disease in patients with type 2 diabetes. A meta-analysis conducted by the CTT (Cholesterol Treatment Trialists) Collaboration ${ }^{180}$ using 14 trials $^{59,60,168,169,174-177,181-186}$ showed that statin therapy reduced the five-year incidence of major vascular events by about $20 \%$ per $\mathrm{mmol} / \mathrm{L}$ reduction in LDL cholesterol, with similar proportional reductions in major coronary events, stroke, and the need for coronary revascularization in type 2 diabetic patients. The meta-analysis also highlighted that the average risk of a major vascular event was about $2.9 \%$ per year in people with type 2 diabetes and no known vascular disease.

CARDS (the Collaborative Atorvastatin Diabetes Study) randomized 2338 patients with type 2 diabetes without high LDL cholesterol and demonstrated that atorvastatin significantly reduced the incidence of new stroke by $48 \%$, independent of patient age, gender, baseline cholesterol, and blood pressure levels. ${ }^{169}$ These findings were confirmed by a subanalysis of the LIPID (Long-term Intervention with Pravastatin in Ischemic Disease) trial, ${ }^{187}$ which showed reductions in stroke of $39 \%$ and $42 \%$ in patients with type 2 diabetes and impaired glucose tolerance, respectively. In HPS (the Heart Protection Study), simvastatin reduced stroke by $25 \%$ in the subgroup of patients with type 2 diabetes. ${ }^{173}$ The Scandinavian Simvastatin Survival Study showed that treatment with simvastatin reduced stroke in a diabetic cohort by $62 \%$ compared with $23 \%$ in subjects without diabetes. ${ }^{188}$

Subgroup analysis of the Helsinki Heart Study, a five-year ischemic heart disease primary prevention trial using gemfibrozil, provided evidence for the potential benefit of lipid-lowering agents in both nondiabetic and type 2 diabetic patients. ${ }^{189}$ The subgroup analysis of VA-HIT (Veterans Affairs High-density lipoprotein Intervention Trial) ${ }^{190,191}$ showed that gemfibrozil reduced coronary heart disease by $39 \%$ in type 2 diabetic patients, but the FIELD (Fenofibrate Intervention and Event Lowering in Diabetes) study ${ }^{192}$ failed to show similar benefits. Post hoc analysis of the FIELD study suggested a benefit for type 2 diabetic patients with marked dyslipidemia. ${ }^{193}$ Recently, the lipid arm of the ACCORD study examined whether combination therapy with a statin and fibrate would be beneficial in reducing cardiovascular disease in type 2 diabetes. The investigation failed to support the routine use of combination therapy with fenofibrate and simvastatin to reduce cardiovascular risk in the majority of high-risk patients with type 2 diabetes as compared with simvastatin alone. ${ }^{194}$

\section{Antiplatelet therapy}

Atherosclerosis and vascular thrombosis are major contributors to diabetic vasculopathy, and it is generally accepted that platelets play a significant role in increasing the risk of cardiovascular disease. ${ }^{31}$ Currently, aspirin is at the center of this research and is widely recommended for primary prevention of cardiovascular events in type 2 diabetic patients. ${ }^{195}$ Aspirin reduces the risk of serious vascular events in patients at high risk by about $25 \%$ and also helps prevent the recurrence of such events as heart attack, hospitalization for recurrent angina, and recurrent strokes. Almost all of the major guidelines recommend aspirin for primary prevention of cardiovascular events in people with type 2 diabetes, based on the evidence extrapolated from trials of high-risk patients. ${ }^{196,197}$ However, the POPADAD (Prevention of Progression of Arterial Disease and Diabetes) tria ${ }^{198}$ demonstrated that aspirin did not prevent a first cardiovascular event or death in type 2 diabetic patients, which contradicts the recommendations made in many guidelines. It recommended that aspirin should be continued for secondary prevention of cardiovascular disease in patients with type 2 diabetes. The JPAD (Japanese Primary Prevention of Atherosclerosis with Aspirin for Diabetes) trial examined the efficacy of low-dose aspirin for the primary prevention of atherosclerotic events in type 2 diabetic patients and concluded that low-dose aspirin as primary prevention did not reduce the risk of cardiovascular events. ${ }^{199}$

A recent meta-analysis ${ }^{200}$ using six trials ${ }^{198,199,201-204}$ (10,117 patients, duration 1966-2008) also could not recommend use of aspirin for primary prevention of cardiovascular events in all patients with type 2 diabetes, and 
suggested waiting for additional evidence from ongoing trials. This analysis suggested that the benefit of aspirin in primary prevention of major cardiovascular events or death in type 2 diabetic patients may be lower than in other highrisk populations. Aspirin significantly reduced the risk of myocardial infarction in men by $43 \%$, whereas no benefit was found in women. Therefore, a clear benefit of aspirin in the primary prevention of major cardiovascular events in type 2 diabetic patients remains unproven and requires evidence from further studies.

Other antiplatelet drugs were also found to reduce the risk of cardiovascular events in type 2 diabetic patients. In a subgroup analysis of the CAPRIE (Clopidogrel versus Aspirin in Patients at Risk of Ischaemic Events) study, patients with type 2 diabetes taking clopidogrel seem to derive enhanced benefit from clopidogrel compared with aspirin. ${ }^{205,206} \mathrm{~A}$ meta-analysis of six randomized trials ${ }^{207-212}$ of GP IIb/IIIa inhibitors in type 2 diabetic patients with acute coronary syndrome showed that these drugs may significantly reduce mortality at 30 days, and recommended serious consideration of these agents in type 2 diabetic patients with acute coronary syndrome. ${ }^{213}$ The subgroup analysis of 362 diabetic patients in the PRISMPLUS (Platelet Inhibition in Ischemic Syndrome Management in Patients Limited by Unstable Signs and Symptoms) trial showed that triple therapy (aspirin, heparin, tirofiban) significantly reduced the incidence of myocardial infarction or death as compared with aspirin plus heparin. ${ }^{214}$

\section{Conclusion}

Type 2 diabetes is a global epidemic with a devastating human, social, and economic impact. The costs of diabetes are enormous, both for health care services and through loss of productivity. The disease is responsible for premature mortality, predominantly through atherosclerotic vascular disease, either macrovascular or microvascular. However, macrovascular complications are more common, and most diabetic patients develop or die of macrovascular disease. Lifestyle modification and pharmacotherapy (tight blood pressure, and lipid and glycemic control) can prevent or delay the development of type 2 diabetes, including cardiovascular outcomes.

Studies have demonstrated that lifestyle interventions reduce cardiovascular risk factors, but evidence for longterm cardiovascular outcomes is lacking. Similarly, intensive glucose control in type 2 diabetic patients also failed to show consistent beneficial effects on cardiovascular events. On the contrary, the evidence shows that diabetic vasculopathy can be improved by lowering blood pressure using antihypertensive drugs, maintaining normal lipid profiles with lipid-lowering agents, and minimizing atherosclerosis and vascular thrombosis with antiplatelet therapy. Above all, patient education and preventive care should be considered as an important way to combat the type 2 diabetes epidemic and its associated cardiovascular complications. A multidisciplinary approach involving patients, health professionals, and diabetic educators is the best strategy by which to bring "radical change" in understanding type 2 diabetes and improving quality of life.

\section{Disclosure}

The authors report no conflict of interest in this work.

\section{References}

1. International Diabetes Federation (IDF). Diabetes Atlas. 4th ed. Brussels: International Diabetes Federation; 2009.

2. Turner R, Cull C, Holman R. United Kingdom Prospective Diabetes Study 17: a9-year update of a randomized, controlled trial on the effect of improved metabolic control on complications in non-insulindependent diabetes mellitus. Ann Intern Med. 1996;124(1 Pt 2): 136-145.

3. American Diabetes Association. Management of dyslipidemia in adults with diabetes. American Diabetes Association: Clinical Practice Recommendations 1999. Diabetes Care. 1999;22:556-559.

4. Rahman S, Ismail AA, Ismail SB, Naing NN, Rahman AR. Early manifestation of macrovasculopathy in newly diagnosed never treated type II diabetic patients with no traditional CVD risk factors. Diabetes Res Clin Pract. 2008;80(2):253-258.

5. Giannattasio C, Failla M, Capra A, et al. Increased arterial stiffness in normoglycemic normotensive offspring of type 2 diabetic parents. Hypertension. 2008;51(2):182-187.

6. Rahman S, Ismail AA, Ismail SB, Naing NN, Rahman AR. Increased arterial stiffness in normoglycaemic offspring of newly diagnosed, never treated type 2 diabetic and impaired glucose tolerance parents. Br J Diabetes Vasc Dis. 2009;9:65-68.

7. Word Health Organisation. Diabetes. Available from: http://www.who. int/mediacentre/factsheets/fs312/en/index.html. Accessed Jun 2011.

8. Williams R, van Gaal L, Lucioni C. Assessing the impact of complications on the costs of Type II diabetes. Diabetologia. 2002; 45(7):S13-S17.

9. Jonsson B; CODE-2 Advisory Board. Revealing the cost of Type II diabetes in Europe. Diabetologia. 2002;45(7):S5-S12.

10. Zimmet P, Shaw J, Alberti KG. Preventing Type 2 diabetes and the dysmetabolic syndrome in the real world: a realistic view. Diabet Med. 2003;20(9):693-702.

11. American Heart Association. Cardiovascular Disease and Diabetes. Available from: http://www.heart.org/HEARTORG/Conditions/ Diabetes/WhyDiabetesMatters/Cardiovascular-Disease-Diabetes_ UCM_313865_Article.jsp. Accessed October 12, 2011.

12. Nathan DM, Cleary PA, Backlund JY, et al. Intensive diabetes treatment and cardiovascular disease in patients with type 1 diabetes. $N$ Engl J Med. 2005;353(25):2643-2653.

13. National Institute of Diabetes and Digestive and Kidney Diseases. National diabetes statistics fact sheet: general information and national estimates on diabetes in the United States, 2005. Bethesda, MD: US Department of Health and Human Services, National Institutes of Health; 2005.

14. Rahman S, Ismail AA, Rahman AR. Treatment of diabetic vasculopathy with rosiglitazone and ramipril: Hype or hope? Int J Diabetes Dev Ctries. 2009;29(3):110-117. 
15. American Diabetes Association. Position statement: Diabetes mellitus and exercise. Diabetes Care. 1990;13(7):804-805.

16. Dela F, Ploug T, Handberg A, et al. Physical training increases muscle GLUT 4 protein and mRNA in patients with NIDDM. Diabetes. 1994; $7: 862-865$.

17. Zanchetti A. Aspirin and antiplatelet drugs in the prevention of cardiovascular complications of diabetes. In: Mogensen CE, editor. Pharmacotheraphy of Diabetes: New Developments. Improving Life and Prognosis for Diabetic Patients. New York, NY: Springer; 2007 : 211-218.

18. IDF Clinical Guidelines Task Force. Global guideline for Type 2 diabetes. Brussels: International Diabetes Federation; 2005.

19. Yeh H, Huang ES, Levin P, Liu S, Brancati FL. Medication Use in Elderly US Adults with Diabetes and the Potential Practice Ramifications of Raising the Glycemic Target, NHANES 2003-2008. Paper presented at the 71st Scientific Sessions; 2011 June 24-28; San Diego, CA: American Diabetes Association; 2011.

20. Selvin E, Coresh J, Golden SH, Brancati FL, Folsom AR, Steffes MW. Glycemic control and coronary heart disease risk in persons with and without diabetes: the atherosclerosis risk in communities study. Arch Intern Med. 2005;165(16):1910-1916.

21. Lebovitz HE, Feinglos MN. Mechanism of action of the secondgeneration sulfonylurea glipizide. Am J Med. 1983;75(5B):46-54

22. Kolterman OG, Gra RS, Shapiro G, Scarlett JA, Griffin J, Olesfsky JM. The acute and chronic effects of sulfonylurea therapy in type II diabetic subjects. Diabetes. 1984;33(4):346-354.

23. Groop L. Metabolic effects of sulfonylurea drugs. A review. Ann Clin Res. 1983:15 Suppl 37:16-20.

24. DeFronzo RA. Pharmacologic therapy for type 2 diabetes mellitus. Ann Intern Med. 1999;131(4):281-303.

25. Feinglos MN, Bethel MA. Treatment of type 2 diabetes mellitus. Med Clin North Am. 1998;82(4):757-790.

26. Luna B, Hughes AT, Feinglos MN. The use of insulin secretagogues in the treatment of type 2 diabetes. Prim Care. 1999;26(4):895-915.

27. Black C, Donnelly P, McIntyre L, Royle PL, Shepherd JP, Thomas S. Meglitinide analogues for type 2 diabetes mellitus. Cochrane Database Syst Rev. 2007;2:CD004654.

28. American Diabetes Association. Standards of medical care in diabetes 2009. Diabetes Care. 2009;32 Suppl 1:S13-S61.

29. Luna B, Feinglos MN. Oral Agents in the management of type 2 diabetes mellitus. Am Fam Physician. 2001;63(9):1747-1756, 1759-1780.

30. DeFronzo RA, Goodman AM. Efficacy of metformin in patients with non-insulin-dependent diabetes mellitus. The Multicenter Metformin Study Group. N Engl J Med. 1995;333(9):541-549.

31. Rahman S, Rahman T, Ismail AA, Rashid AR. Diabetes-associated macrovasculopathy: pathophysiology and pathogenesis. Diabetes Obes Metab. 2007;9(6):767-780.

32. Hughes K, Aw TC, Kuperan P, Choo M. Central obesity, insulin resistance, syndrome $\mathrm{X}$, lipoprotein(a), and cardiovascular risk in Indians, Malays, and Chinese in Singapore. J Epidemiol Community Health. 1997;51(4):394-399.

33. Nesto RW, Bell D, Bonow RO, et al; American Heart Association; American Diabetes Association. Thiazolidinedione use, fluid retention, and congestive heart failure: a consensus statement from the American Heart Association and American Diabetes Association. October 7, 2003. Circulation. 2003;108(23):2941-2948.

34. Nissen SE, Wolski K. Effect of rosiglitazone on the risk of myocardial infarction and death from cardiovascular causes. N Engl J Med. 2007; 356(24):2457-2471.

35. Lincoff AM, Wolski K, Nicholls SJ, Nissen SE. Pioglitazone and risk of cardiovascular events in patients with type 2 diabetes mellitus: a meta-analysis of randomized trials. JAMA. 2007;298(10): 1180-1188.

36. Graham DJ, Ouellet-Hellstrom R, MaCurdy TE, et al. Risk of acute myocardial infarction, stroke, heart failure, and death in elderly Medicare patients treated with rosiglitazone or pioglitazone. JAMA. 2010;304(4):411-418.
37. Food and Drug Administration(FDA). FDA Drug Safety Communication: Update to ongoing safety review of Actos (pioglitazone) and increased risk of bladder cancer. Available from: http://www.fda.gov/Drugs/ DrugSafety/ucm259150.htm. Accessed September 30, 2011.

38. Hanefeld M, Schaper F. The role of alpha-glucosidase inhibitors (Acarbose). In: Mogensen CE, editor. Pharmacotheraphy of Diabetes: New Developments. Improving Life and Prognosis for Diabetic Patients. New York, NY: Springer; 2007:143-152.

39. Chiasson JL, Josse RG, Hunt JA, et al. The efficacy of acarbose in the treatment of patients with non-insulin-dependent diabetes mellitus. A multicenter controlled clinical trial. Ann Intern Med. 1994;121(12): 928-935.

40. Rodger NW, Chiasson JL, Josse RG, et al. Clinical experience with acarbose: results of a Canadian multicentre study. Clin Invest Med. 1995;18(4):318-324.

41. McDougall C, McKay GA, Fisher M. Drugs for diabetes: part 6 GLP-1 receptor agonists. Br J Cardiol. 2011;18:167-169.

42. McDougall C, McKay GA, Fisher M. Drugs for diabetes: part 5 DPP-4 inhibitors. Br J Cardiol. 2011;18:130-132.

43. Nauck M, Smith U. Incretin-based therapy: how do incretinmimetics and DPP-4 inhibitors fit into treatment algorithms for type 2 diabetic patients? Best Pract Res Clin Endocrinol Metab. 2009;23(4):513-523.

44. Siddiqui NI. Incretinmimetics and DPP-4 inhibitors: new approach to treatment of type 2 diabetes mellitus. Mymensingh Med J. 2009;18(1):113-124. Available from: http://www.ncbi.nlm.nih.gov/ pubmed/19182763.

45. Joint National Committee on Prevention, Detection, Evaluation, and Treatment of High Blood Pressure. The Seventh Report of the Joint National Committee on Prevention, Detection, Evaluation and Treatment of High Blood Pressure. Bethesda, MD: National Heart, Lung, and Blood Institute (US); 2004.

46. Voulgari C, Papadogiannis D, Tentolouris N. Diabetic cardiomyopathy: from the pathophysiology of the cardiac myocytes to current diagnosis and management strategies. Vasc Health Risk Managt. 2010;6: 883-903.

47. American Diabetes Association. Treatment of hypertension in adults with diabetes. Diabetes Care. 2003;26:S80-S82.

48. Hansson L, Zanchetti A, Carruthers SG, et al. Effects of intensive bloodpressure lowering and low-dose aspirin in patients with hypertension: principal results of the Hypertension Optimal Treatment (HOT) randomised trial. HOT Study Group. Lancet. 1998;351(9118):1755-1762.

49. UK Prospective Diabetes Study (UKPDS) Group. Intensive bloodglucose control with sulphonylureas or insulin compared with conventional treatment and risk of complications in patients with type 2 diabetes (UKPDS 33). Lancet. 1998;352(9131):837-853.

50. UK Prospective Diabetes Study Group. Tight blood pressure control and risk of macrovascular and microvascular complications in type 2 diabetes: UKPDS 38. BMJ. 1998;317(7160):703-713.

51. Tuomilehto J, Rastenyte D, Birkenhäger WH, et al. Effects of calcium-channel blockade in older patients with diabetes and systolic hypertension. Systolic Hypertension in Europe Trial Investigators. N Engl J Med. 1999;340(9):677-684.

52. Curb JD, Pressel SL, Cutler JA, et al. Effect of diuretic-based antihypertensive treatment on cardiovascular disease risk in older diabetic patients with isolated systolic hypertension. Systolic Hypertension in the Elderly Program Cooperative Research Group. JAMA. 1996; 276(23):1886-1892.

53. McFarlane SI, Kumar A, Sowers JR. Mechanisms by which angiotensin converting enzyme inhibitors prevent diabetes and cardiovascular disease. Am J Cardiol. 2003;91(12A):30H-37H.

54. McFarlane SI. Role of angiotensin receptor blockers in diabetes: implications of recent clinical trials. Expert Rev Cardiovasc Ther. 2009; 7(11):1363-1371.

55. Lindholm LH, Ibsen H, Dahlof B, et al. Cardiovascular morbidity and mortality in patients with diabetes in the Losartan Intervention for Endpoint reduction in hypertension study (LIFE): a randomised trial against atenolol. Lancet. 2002;359(9311):1004-1010. 
56. Mayor S. Calcium channel blockers associated with less diabetes. $B M J$. 2006;333(7567):514.

57. Pyörälä K, Pedersen TR, Kjekshus J, Faergeman O, Olsson AG, Thorgeirsson G. Cholesterol lowering with simvastatin improves prognosis of diabetic patients with coronary heart disease. A subgroup analysis of the Scandinavian Simvastatin Survival Study (4S). Diabetes Care. 1997;20(4):614-620.

58. Koskinen P, Manttari M, Manninen V, Huttunen JK, Heinonen OP, Frick MH. Coronary heart disease incidence in NIDDM patients in the Helsinki Heart Study. Diabetes Care. 1992;15(7):820-825.

59. Sacks FM, Pfeffer MA, Moye LA, et al. The effect of pravastatin on coronary events after myocardial infarction in patients with average cholesterol levels. Cholesterol and Recurrent Events Trial investigators. N Engl J Med. 1996;335(14):1001-1009.

60. The Long-term Intervention with Pravastatin in Ischaemic Disease (LIPID) Study Group. Prevention of cardiovascular events and death with pravastatin in patients with coronary heart disease and a broad range of initial cholesterol levels. N Engl J Med. 1998;339(19):1349-1357.

61. Elkeles RS, Diamond JR, Poulter C, et al. Cardiovascular outcomes in type 2 diabetes. A double-blind placebo-controlled study of bezafibrate: the St Mary's, Ealing, Northwick Park Diabetes Cardiovascular Disease Prevention (SENDCAP) Study. Diabetes Care. 1998;21(4): 641-648.

62. Rubins HB, Robins SJ, Collins D, et al. Gemfibrozil for the secondary prevention of coronary heart disease in men with low levels of highdensity lipoprotein cholesterol. N Engl J Med. 1999;341(6):410-418.

63. Diabetes Atherosclerosis Intervention Study Investigators. Effect of fenofibrate on progression of coronary-artery disease in type 2 diabetes: the Diabetes Atherosclerosis Intervention Study, a randomised study. Lancet. 2001;357(9260):905-910.

64. Sattar N, Preiss D, Murray HM, et al. Statins and risk of incident diabetes: a collaborative meta-analysis of randomised statin trials. Lancet. 2010;375(9716):735-742.

65. Preiss D, Seshasai SR, Welsh P, et al. Risk of incident diabetes with intensive dose compared with moderate dose statin therapy. A Meta-analysis. JAMA. 2011;305(24):2556-2564.

66. Beckman JA, Creager MA, Libby P. Diabetes and atherosclerosis: epidemiology, pathophysiology, and management. JAMA. 2002; 287(19):2570-2581.

67. Hankey GJ, Eikelboom JW. Antiplatelet drugs. Med J Aust. 2003; 178(11):568-574.

68. Gillies CL, Abrams KR, Lambert PC, et al. Pharmacological and lifestyle interventions to prevent or delay type 2 diabetes in people with impaired glucose tolerance: systematic review and meta-analysis. $B M J$. 2007;334(7588):299.

69. Richelsen B. Obesity and pharmacological treatment. In: Mogensen CE, editor. Pharmacotheraphy of Diabetes: New Developments. Improving Life and Prognosis for Diabetic Patients. New York, NY: Springer; 2007:167-171.

70. Eckel RH, Krauss RM. American Heart Association call to action: obesity as a major risk factor for coronary heart disease. AHA Nutrition Committee. Circulation. 1998;97(21):2099-2100.

71. Franz MJ, Bantle JP, Beebe CA, et al. Evidence-based nutrition principles and recommendations for the treatment and prevention of diabetes and related complications. Diabetes Care. 2002;25(1):148-198.

72. Goldstein DJ. Beneficial health effects of modest weight loss. Int $J$ Obes Relat Metab Disord. 1992;16(6):397-415.

73. Abraham WT. Preventing cardiovascular events in patients with diabetes mellitus. Am J Med. 2004;116 Suppl 5A:39S-46S.

74. Castaneda C, Layne JE, Munoz-Orians L, et al. A randomized controlled trial of resistance exercise training to improve glycemic control in older adults with type 2 diabetes. Diabetes Care. 2002;25(12):2335-2341.

75. American Diabetes Association. Diabetes mellitus and exercise. Diabetes Care. 2002;25 Suppl 1:S64-S68.

76. Stiegler RS, Zimmet PZ, Cameron AJ, et al. Lifestyle management: preventing Type 2 diabetes and cardiovascular complications. Therapy. 2009;6(4):489-496.
77. The Look AHEAD Research Group. Reduction in weight and cardiovascular disease risk factors in individuals with type 2 diabetes: one-year results of the look AHEAD trial. Diabetes Care. 2007;30(6):1374-1383.

78. Redmon JB, Bertoni AG, Connelly S, et al. Effect of the look AHEAD study intervention on medication use and related cost to treat cardiovascular disease risk factors in individuals with type 2 diabetes. Diabetes Care. 2010;33(6):1153-1158.

79. Wadden TA, West DS, Neiberg RH, et al. Look AHEAD Research Group. One-year weight losses in the Look AHEAD study: factors associated with success. Obesity (Silver Spring). 2009;17(4):713-722.

80. Li G, Zhang P, Wang J, et al. The long-term effect of lifestyle interventions to prevent diabetes in the China Da Qing Diabetes Prevention Study: a 20-year follow-up study. Lancet. 2008;371(9626):1783-1789.

81. Lindstrom J, Ilanne-Parikka P, Peltonen M, et al; Finnish Diabetes Prevention Study Group. Sustained reduction in the incidence of type 2 diabetes by lifestyle intervention: follow-up of the Finnish Diabetes Prevention Study. Lancet. 2006;368(9548):1673-1679.

82. Eriksson KF, Lindagarde F. Prevention of type 2 (non-insulin-dependent) diabetes mellitus by diet and physical exercise. The 6-year Malmo feasibility study. Diabetologia. 1991;34(12):891-898.

83. Pan X, Li G, Hu Y, et al. Effects of diet and exercise in preventing NIDDM in people with impaired glucose tolerance. The Da Qing IGT and Diabetes Study. Diabetes Care. 1997;20(4):537-544.

84. Tuomilehto J, Lindström J, Eriksson JG, et al; Finnish Diabetes Prevention Study Group. Prevention of type 2 diabetes mellitus by changes in lifestyle among subjects with impaired glucose tolerance. N Engl J Med. 2001;344(18):1343-1350.

85. Knowler WC, Hamman RF, Edelstein SL, et al; Diabetes Prevention Program Research Group. Prevention of type 2 diabetes with troglitazone in the Diabetes Prevention Program. Diabetes. 2005;54(4):1150-1156.

86. Kosaka K, Noda M, Kuzuya T. Prevention of type 2 diabetes by lifestyle intervention: a Japanese trial in IGT males. Diabetes Res Clin Pract. 2005;67(2):152-162.

87. Ramachandran A, Snehalatha C, Mary S, Mukesh B, Bhaskar AD, Vijay V; Indian Diabetes Prevention Programme (IDPP). The Indian Diabetes Prevention Programme shows that lifestyle modification and metformin prevent type 2 diabetes in Asian Indian subjects with impaired glucose tolerance (IDPP-1). Diabetologia. 2006;49(2):289-297.

88. Orozco LJ, Buchleitner AM, Gimenez-Perez G, Roque I Figuls M, Richter B, Mauricio D. Exercise or exercise and diet for preventing type 2 diabetes mellitus. Cochrane Database Syst Rev. 2008;16(3): CD003054.

89. Bo S, Ciccone G, Baldi C, et al. Effectiveness of a lifestyle intervention on metabolic syndrome. A randomized controlled trial. J Gen Intern Med. 2007;22(12):1695-1703.

90. Wing RR, Venditti E, Jakicic JM, Polley BA, Lang W. Lifestyle intervention in overweight individual with a family history of diabetes. Diabetes Care. 1998;21(3):350-359.

91. Oldroyd JC, Unwin NC, White M, Imrie K, Mathers JC, Alberti KG. Randomised controlled trial evaluating the effectiveness of behavioural interventions to modify cardiovascular risk factors in men and women with impaired glucose tolerance: outcomes at 6 month. Diabetes Res Clin Pract. 2001;52(1):29-43.

92. Lindstrom J, Louheranta A, Mannelin M, et al. The Finnish Diabetes Prevention Study (DPS): Lifestyle intervention and 3-year results on diet and physical activity. Diabetes Care. 2003;26(12):3230-3236.

93. Crandall J, Schade D, Ma Y, et al. The influence of age on the effects of lifestyle modification and metformin in prevention of diabetes. J Gerontol A Biol Sci Medl Sci. 2006;61(10):1075-1081.

94. Khaw KT, Wareham N, Luben R, et al. Glycated haemoglobin, diabetes, and mortality in men in Norfolk cohort of European prospective investigation of cancer and nutrition (EPIC-Norfolk). BMJ. 2001; 322(7277): 15-18.

95. Standl E, Balletshofer B, Dahl B, et al. Predictors of 10-year macrovascular and overall mortality in patients with NIDDM: the Munich General Practitioner Project. Diabetologia. 1996;39(12):1540-1545. 
96. Stratton IM, Adler AI, Neil HA, et al. Association of glycaemia with macrovascular and microvascular complications of type 2 diabetes (UKPDS 35): prospective observational study. BMJ. 2000;321(7258): 405-412.

97. UK Prospective Diabetes Study (UKPDS) Group. Effect of intensive blood-glucose control with metformin on complications in overweight patients with type 2 diabetes (UKPDS 34). Lancet. 1998;352(9131): 854-865.

98. Patel A, MacMahon S, Chalmers J, et al. Intensive blood glucose control and vascular outcomes in patients with type 2 diabetes. $N$ Engl J Med. 2008;358(24):2560-2572.

99. Schor S. The University Group Diabetes Program. A statistician looks at the mortality results. JAMA. 1971;217(12):1671-1675.

100. Action to Control Cardiovascular Risk in Diabetes Study Group. Effects of intensive glucose lowering in type 2 diabetes. $N$ Engl J Med. 2008;358(24):2545-2559.

101. Shichiri M, Kishikawa H, Ohkubo Y, Wake N. Long-term results of the Kumamoto Study on optimal diabetes control in type 2 diabetic patients. Diabetes Care. 2000;23 Suppl 2:B21-B29.

102. Holman RR, Paul SK, Bethel MA, Matthews DR, Neil HA. 10-year follow-up of intensive glucose control in type 2 diabetes. $N$ Engl $J$ Med. 2008;359(15):1577-1589.

103. Duckworth W, Abraira C, Moritz T, et al; VADT Investigators. Glucose control and vascular complications in veterans with type 2 diabetes. N Engl J Med. 2009;360(2):129-139.

104. Nathan DM. Navigating the choices for diabetes prevention. $N$ Engl J Med. 2010;362(16):1533-1535.

105. Wilcox R, Kupfer S, Erdmann E; PROactive Study investigators. Effects of pioglitazone on major adverse cardiovascular events in high-risk patients with type 2 diabetes: results from PROspectivepioglitAzone Clinical Trial In macro Vascular Events (PROactive 10). Am Heart J. 2008;155(4):712-717.

106. Dormandy JA, Charbonnel B, Eckland DJ, et al; PROactive investigators. Secondary prevention of macrovascular events in patients with type 2 diabetes in the PROactive Study (PROspectivepioglitAzone Clinical Trial In macroVascular Events): a randomised controlled trial. Lancet. 2005;366(9493):1279-1289.

107. Ray KK, Seshasai SK, Wijesuriya S, et al. Effect of intensive control of glucose on cardiovascular outcomes and death in patients with diabetes mellitus: a meta-analysis of randomised controlled trials. Lancet. 2009;373(9677):1765-1772.

108. Abraira C, Duckworth W, McCarren M, et al; VA Cooperative Study of Glycemic Control and Complications in Diabetes Mellitus Type 2. Design of the cooperative study on glycemic control and complications in diabetes mellitus type 2: Veterans Affairs Diabetes Trial. J Diabetes Complications. 2003;17(6):314-322.

109. Charbonnel B, Dormandy J, Erdmann E, Massi-Benedetti M, Skene A; PROactive Study Group. The prospective pioglitazone clinical trial in macrovascular events (PROactive): can pioglitazone reduce cardiovascular events in diabetes? Study design and baseline characteristics of 5238 patients. Diabetes Care. 2004;27(7):1647-1653.

110. Marso SP, Kennedy KF, House JA, McGuire DK. The effect of intensive glucose control on all-cause and cardiovascular mortality, myocardial infarction and stroke in persons with type 2 diabetes mellitus: a systematic review and meta-analysis. Diab Vasc Dis Res. 2010;7(2):119-130.

111. Abraira C, Colwell J, Nuttall F, et al. Cardiovascular events and correlates in the Veterans Affairs Diabetes Feasibility Trial. Veterans Affairs Cooperative Study on Glycemic Control and Complications in Type II Diabetes. Arch Intern Med. 1997;157(2):181-188.

112. Kelly TN, Bazzano LA, Fonseca VA, Thethi TK, Reynolds K, He J. Systematic review: glucose control and cardiovascular disease in type 2 diabetes. Ann Intern Med. 2009;151(6):394.

113. Coutinho M, Gerstein HC, Wang Y, Yusuf S. The relationship between glucose and incident cardiovascular events. A metaregression analysis of published data from 20 studies of 95,783 individuals followed for 12.4 years. Diabetes Care. 1999;22(2):233-420.
114. Stamler R, Stamler J, Lindberg HA, et al. Asymptomatic hyperglycemia and coronary heart disease in middle-aged men in two employed populations in Chicago. J Chronic Dis. 1979;32(11-12): $805-815$

115. Stenhouse NS, Murphy BP, Welborn TA. Busselton population study: risk associated with asymptomatic hyperglycemia. J Chron Dis. 1979; 32(11-12):693-698.

116. Pyorala K, Savolainen E, Lehtovirta E, Punsar S, Siltanen P. Glucose tolerance and coronary heart disease: Helsinki policemen study. J Chron Dis. 1979;32(11-12):729-745.

117. Fuller JH, Shipley MJ, Rose G, Jarrett RJ, Keen H. Mortality from coronary heart disease and stroke in relation to degree of glycemia: the Whitehall Study. Br Med J. 1983;287(6396):867-870.

118. Donahue RP, Abbott RD, Reed DM, Yano K. Postchallenge glucose concentration and coronary heart disease in men of Japanese ancestry: Honolulu Heart Program. Diabetes. 1987;36(6):689-692.

119. Scheidt-Nave C, Barrett-Connor E, Wingard DL, Cohn BA, Edelstein SL. Sex differences in fasting glycemia as a risk factor for ischemic heart disease death. Am J Epidemiol. 1991;133(6):565-576.

120. Vaccaro O, Ruth KJ, Stamler J. Relationship of postload plasma glucose to mortality with 19-year follow-up. Diabetes Care. 1992; 15(10):1328-1334

121. Balkau B, Eschwege E, Papoz L, et al. Risk factors for early death in non-insulin dependent diabetes and men with known glucose tolerance status. BMJ. 1993;307(6899):295-299.

122. Tuomilehto J, Schranz A, Aldana D, Pitkaniemi J. The effect of diabetes and impaired glucose tolerance on mortality in Malta. Diabet Med. 1994;11(2):170-176.

123. Perry IJ, Wannamethee SG, Whincup PH, Shaper AG. Asymptomatic hyperglycaemia and major ischemic heart disease events in Britain. J Epidemiol Comm Health. 1994;48(6):538-542.

124. Shaten BJ, Kuller LH, Neaton JD. Association between baseline risk factors, cigarette smoking, and CHD mortality after 10.5 years. MRFIT Research Group. Prev Med. 1991;20(5):655-669.

125. Da Silva A, Widmer LK, Ziegler HW, Nissen C, Schweizer W. The Basle longitudinal study: report on the relation of initial glucose level to baseline ECG abnormalities, peripheralartery disease, and subsequent mortality. J Chronic Dis. 1979;32(11-12): 797-803

126. Hawthorne VM, Gilmour WH. Relationship of glucose to prevalence of ECG abnormalities at baseline and to 6-year mortality in Scottish males aged 45-64 yr. J Chron Dis. 1979;32(11-12):787-796.

127. Reunanen A, Pyorala K, Aromaa A, Maatela J, Knekt P. Glucose tolerance and coronary heart disease in middle aged Finnish men: Social Insurance Institution's Coronary Heart Disease Study. J Chron Dis. 1979;32(11-12):747-758.

128. Cruz-Vidal M, Garcia-Palmieri MR, Costas R, Sorlie PD, Havlik RJ. Abnormal blood glucose and coronary heart disease: the Puerto Rico Heart Health Program. Diabetes Care. 1983;6(6):556-561.

129. Yarnell JW, Pickering JE, Elwood PC, et al. Does nondiabetichyperglycemia predict future IHD? Evidence from the Caerphilly and Speedwell studies. J Clin Epidemiol. 1994;47(4):383-388.

130. Schroll M, Hagerup L. Relationship of fastingblood glucose to prevalence of ECG abnormalities and 10-year risk of mortality from cardiovascular diseases in men born in 1914: from the Glostrup Population Studies. J Chron Dis. 1979;32(11-12):699-707.

131. Ohlson LO, Svardsudd K, Welin L, et al. Fasting blood glucose and risk of coronary heart disease, stroke, and all-cause mortality: a 17-year follow-up study of men born in 1913. Diabetic Med. 1986; 3(1):33-37.

132. Haheim LL, Holme I, Hjermann I, Leren P. Nonfasting serum glucose and the risk of fatal stroke in diabetic and nondiabetic subjects: 18-year follow-up of the Oslo study. Stroke. 1995;26(5):774-777.

133. Grabauskas VJ. Glucose intolerance as contributor to noncommunicable disease morbidity and mortality. WHO integrated program for community health in noncommunicable diseases. Diabetes Care. 1988;11(3):253-257. 
134. Pyorala K, Savolainen E, Kaukola S, Haapakoski J. Plasma insulin as coronary heart disease risk factor: relationship to other risk factors and predictive value during 91/2-year follow-up of the Helsinki Policemen Study population. Acta Med Scand Suppl. 1985;701:38-52.

135. Turnbull FM, Abraira C, Anderson RJ, et al; Control Group. Intensive glucose control and macrovascular outcomes in type 2 diabetes. Diabetologia. 2009;52(11):2288-2298.

136. SHEP Cooperative Research Group. Prevention of stroke by antihypertensive drug treatment in older persons with isolated systolic hypertension. Final results of the Systolic Hypertension in the Elderly Program (SHEP). JAMA. 1991;265(24):3255-3264.

137. Staessen JA, Fagard R, Thijs L, et al. Randomised double-blind comparison of placebo and active treatment for older patients with isolated systolic hypertension. The Systolic Hypertension in Europe (Syst-Eur) Trial Investigators. Lancet. 1997;350(9080): 757-764.

138. Staessen JA, Thijs L, Gasowski J, Cells H, Fagard RH. Treatment of isolated systolic hypertension in the elderly: further evidence from the systolic hypertension in Europe (Syst-Eur) trial. Am J Cardiol. 1998; 82(9B):20R-22R.

139. Voyaki SM, Staessen JA, Thijs L, et al. Follow-up of renal function in treated and untreated older patients with isolated systolic hypertension. Systolic Hypertension in Europe (Syst-Eur) Trial Investigators. J Hypertens. 2001;19(3):511-519.

140. Heart Outcomes Prevention Evaluation (HOPE) Study Investigators. Effects of ramipril on cardiovascular and microvascular outcomes in people with diabetes mellitus: results of the HOPE study and MICROHOPE substudy. Lancet. 2000;355(9200):253-259.

141. Dahlöf B, Devereux RB, Kjeldsen SE, et al. Cardiovascular morbidity and mortality in the Losartan Intervention For Endpoint reduction in hypertension study (LIFE): a randomised trial against atenolol. Lancet. 2002;359(9311):995-1003.

142. ALLHAT Officers and Coordinators for the ALLHAT Collaborative Research Group. Major outcomes in high-risk hypertensive patients randomized to angiotensin-converting enzyme inhibitor or calcium channel blocker vs diuretic: The Antihypertensive and Lipid-Lowering Treatment to Prevent Heart Attack Trial (ALLHAT). JAMA. 2002; 288(23):2981-2997.

143. Chobanian AV, Bakris GL, Black HR, et al. The seventh Report of the Joint National Committee on Prevention, Detection, Evaluation, and Treatment of High Blood Pressure: the JNC 7 report. JAMA. 2003; 289(19):2560-2572.

144. Adler AI, Stratton IM, Neil HA, et al. Association of systolic blood pressure with macrovascular and microvascular complications of type 2 diabetes (UKPDS 36): prospective observational study. BMJ. 2000;321(7258):412-419.

145. Yusuf S, Sleight P, Pogue J, Bosch J, Davies R, Dagenais G. Effects of an angiotensin-converting-enzyme inhibitor, ramipril, on cardiovascular events in high-risk patients. The Heart Outcomes Prevention Evaluation Study Investigators. NEngl J Med. 2000;342(3): 145-153.

146. Teo K, Yusuf S, Sleight P, Anderson C, et al; ONTARGET/ TRANSCEND Investigators. Rationale, design, and baseline characteristics of 2 large, simple, randomized trials evaluating telmisartan, ramipril, and their combination in high-risk patients: the Ongoing Telmisartan Alone and in Combination with Ramipril Global Endpoint Trial/Telmisartan Randomized Assessment Study in ACE Intolerant Subjects with Cardiovascular Disease (ONTARGET/ TRANSCEND) trials. Am Heart J. 2004;148(1):52-61.

147. Sawicki PT, Siebenhofer A. Beta-blockers and diabetes mellitus. J Clin Basic Cardiol. 2001;4:17-20.

148. Niskanen L, Hedner T, Hansson L, Lanke J, Niklaston A; CAPPP Study Group. Reduced cardiovascular morbidity and mortality in hypertensive diabetic patients on first-line therapy with an ACE inhibitor compared with a diuretic/beta-blocker-based treatment regimen: a subanalysis of the Captopril Prevention Project. Diabetes Care. 2001;24(12):2091-2096.
149. Dahlof B, Sever PS, Poulter NR, et al; ASCOT Investigators. Prevention of cardiovascular events with an antihypertensive regimen of amlodipine adding perindopril as required versus atenolol adding bendroflumethiazide as required, in the Anglo-Scandinavian Cardiac Outcomes Trial Blood Pressure Lowering Arm (ASCOT-BPLA): a multicentre randomised controlled trial. Lancet. 2005;366(9489): 895-906.

150. Balamuthusamy S, Molnar J, Adigopula S, Arora R. Comparative analysis of beta-blockers with other antihypertensive agents on cardiovascular outcomes in hypertensive patients with diabetes mellitus: a systematic review and meta-analysis. Am J Ther. 2009; 16(2):133-142.

151. Grossman E, Messerli FH. Are calcium antagonists beneficial in diabetic patients with hypertension? Am J Med. 2004;116(1): 44-49.

152. Estacio RO, Schrier RW. Antihypertensive therapy in type 2 diabetes: implications of the appropriate blood pressure control in diabetes (ABCD) trial. Am J Cardiol. 1998;82(9B):9R-14R.

153. Estacio RO, Jeffers BW, Hiatt WR, Biggerstaff SL, Gifford N, Schrier RW. The effect of nisoldipine as compared with enalapril on cardiovascular outcomes in patients with non-insulin-dependent diabetes and hypertension. N Engl J Med. 1998;338(10):645-652.

154. Tatti P, Pahor M, Byington RP, et al. Outcome results of the Fosinopril Versus Amlodipine Cardiovascular Events Randomized Trial (FACET) in patients with hypertension and NIDDM. Diabetes Care. 1998;21(4):597-603.

155. Wang JG, Staessen JA, Liu LS. Subgroup analysis of the placebocontrolled Chinese trial on isolated systolic hypertension in the elderly. J Hypertens. 1999;17 Suppl 3:S86. Available from: http://www.sciencedirect.com/science/article/pii/S000293430300 6053-bbib13.

156. UK Prospective Diabetes Study Group. Efficacy of atenolol and captopril in reducing risk of macrovascular and microvascular complications in type 2 diabetes: UKPDS 39. BMJ. 1998;317(7160):713-720.

157. Hansson L, Lindholm LH, Ekbom T, et al. Randomized trial of old and new antihypertensive drugs in elderly patients: cardiovascular mortality and morbidity the Swedish Trial in Old Patients with Hypertension-2 study. Lancet. 1999;354(9192):1751-1756.

158. Lindholm LH, Hansson L, Ekbom T, et al. Comparison of antihypertensive treatments in preventing cardiovascular events in elderly diabetic patients: results from the Swedish Trial in Old Patients with Hypertension-2. STOP Hypertension-2 Study Group. J Hypertens. 2000;18(11):1671-1675.

159. Mancia G, Brown M, Castaigne A, et al. Outcomes with nifedipine GITS or Co-amilozide in hypertensive diabetics and nondiabetics in Intervention as a Goal in Hypertension (INSIGHT). Hypertension. 2003;41(3):431-436.

160. Lewis EJ, Hunsicker LG, Clarke WR, et al. Renoprotective effect of the angiotensin-receptor antagonist irbesartan in patients with nephropathy due to type 2 diabetes. $N$ Engl J Med. 2001;345(12): 851-860.

161. Berl T, Hunsicker LG, Lewis JB, et al. Cardiovascular outcomes in the Irbesartan Diabetic Nephropathy Trial of patients with type 2 diabetes and overt nephropathy. Ann Intern Med. 2003;138(7):542-549.

162. Vijan, S, Hayward RA. Treatment of hypertension in type 2 diabetes mellitus: blood pressure goals, choice of agents, and setting priorities in diabetes care. Ann Intern Med. 2003;138(7):593-602.

163. Fuller J, Stevens LK, Chaturvedi N, Holloway JF. WITHDRAWN: Antihypertensive therapy for preventing cardiovascular complications in people with diabetes mellitus. Cochrane Database Syst Rev. 2007;4:CD002188.

164. Estacio RO, Jeffers BW, Gifford N, Schrier RW. Effect of blood pressure control on diabetic microvascular complications in patients with hypertension and type 2 diabetes. Diabetes Care. 2000;23 Suppl 2: B54-B64.

165. Wang JG, Staessen JA, Gong L, Liu L. Chinese trial on isolated systolic hypertension in the elderly. Systolic Hypertension in China (Syst-China) Collaborative Group. Arch Intern Med. 2000;160(2): 211-220. 
166. Watkins PJ. ABC of diabetes, cardiovascular disease, hypertension, and lipids. BMJ. 2003;326:874-1186.

167. Georg P, Ludvik B. Lipids and diabetes. J Clin Basic Cardiol. 2000; 3:159-162.

168. Heart Protection Study Collaborative Group. MRC/BHF Heart Protection Study of cholesterol lowering with simvastatin in 20,536 high-risk individuals: a randomised placebo-controlled trial. Lancet. 2002;360(9326):7-22.

169. Colhoun HM, Betteridge DJ, Durrington PN, et al; CARDS investigators. Primary prevention of cardiovascular disease with atorvastatin in type 2 diabetes in the Collaborative Atorvastatin Diabetes Study (CARDS): multicentre randomised placebo-controlled trial. Lancet. 2004;364(9435):685-696.

170. Ridker PM, Danielson E, Fonseca FA, et al; JUPITER Study Group. Rosuvastatin to prevent vascular events in men and women with elevated C-reactive protein. $N$ Engl J Med. 2008;359(21): 2195-2207.

171. Nakamura H, Arakawa K, Itakura H, et al. Primary prevention of cardiovascular disease with pravastatin in Japan (MEGA Study): a prospective randomised controlled trial. Lancet. 2006;368(9542): $1155-1163$.

172. Knopp RH, d'Emden M, Smilde JG, Pocock SJ. Efficacy and safety of atorvastatin in the prevention of cardiovascular end points in subjects with type 2 diabetes: the Atorvastatin Study for Prevention of Coronary Heart Disease Endpoints in non-insulin-dependent diabetes mellitus (ASPEN). Diabetes Care. 2006;29(7):1478-1485.

173. Collins R, Armitage J, Parish S, Sleigh P, Peto R. MRC/BHF Heart Protection Study of cholesterol-lowering with simvastatin in 5963 people with diabetes: a randomised placebo-controlled trial. Lancet. 2003;361(9374):2005-2016.

174. Shepherd J, Blauw GJ, Murphy MB, et al. Pravastatin in elderly individuals at risk of vascular disease (PROSPER): a randomised controlled trial. Lancet. 2002;360(9346):1623-1630.

175. ALLHAT Officers and Coordinators for the ALLHAT Collaborative Research Group. Major outcomes in moderately hypercholesterolemic, hypertensive patients randomized to pravastatin vs usual care: The Antihypertensive and Lipid-Lowering Treatment to Prevent Heart Attack Trial (ALLHAT-LLT). JAMA. 2002;288(23):2998-3007.

176. Downs JR, Clearfield M, Weis S, et al. Primary prevention of acute coronary events with lovastatin in men and women with average cholesterol levels: results of AFCAPS/TexCAPS. Air Force/Texas Coronary Atherosclerosis Prevention Study. JAMA. 1998;279(20): $1615-1622$.

177. Shepherd J, Cobbe SM, Ford I, et al. Prevention of coronary heart disease with pravastatin in men with hypercholesterolemia. West of Scotland Coronary Prevention Study Group. N Engl J Med. 1995; 333(20):1301-1307.

178. Sever PS, Poulter NR, Dahlof B, et al. The Anglo-Scandinavian Cardiac Outcomes Trial lipid lowering arm: extended observations 2 years after trial closure. Eur Heart J. 2008;29(4):499-508.

179. Brugts JJ, Yetgin T, Hoeks SE, et al. The benefits of statins in people without established cardiovascular disease but with cardiovascular risk factors: meta-analysis of randomised controlled trials. BMJ. 2009; 338:b2376.

180. Cholesterol Treatment Trialists' (CTT) Collaborators. Efficacy of cholesterol-lowering therapy in 18,686 people with diabetes in 14 randomized trials of statins: a meta-analysis. Lancet. 2008;371(9607): $117-125$.

181. Scandinavian Simvastatin Survival Study Group. Randomised trial of cholesterol lowering in 4444 patients with coronary heart disease: the Scandinavian Simvastatin Survival Study (4S). Lancet. 1994; 344(8934):1383-1389.

182. The Post Coronary Artery Bypass Graft Trial Investigators. The effect of aggressive lowering of low-density lipoprotein cholesterol levels and low-dose anticoagulation on obstructive changes in saphenous-vein coronary-artery bypass grafts. The Post Coronary Artery Bypass Graft Trial Investigators. N Engl J Med. 1997;336(3):153-162.
183. GISSI Prevenzione Investigators (GruppoItaliano per lo Studio de 1laSopravvivenzanell'InfartoMiocardico). Results of the low-dose $(20 \mathrm{mg})$ pravastatin GISSI Prevenzione trial in 4271 patients with recent myocardial infarction: do stopped trials contribute to overall knowledge? Ital Heart J. 2000;1(12):810-820.

184. Serruys PW, de Feyter P, Macaya C, et al; Lescol Intervention Prevention Study (LIPS) Investigators. Fluvastatin for prevention of cardiac events following successful first percutaneous coronary intervention: a randomized controlled trial. JAMA. 2002;287(24): 3215-3222.

185. Sever PS, Dahlof B, Poulter NR, et al; ASCOT investigators. Prevention of coronary and stroke events with atorvastatin in hypertensive patients who have average or lower-than-average cholesterol concentrations, in the Anglo-Scandinavian Cardiac Outcomes Trial - Lipid Lowering Arm (ASCOT-LLA): a multicentre randomised controlled trial. Lancet. 2003;361(9364):1149-1158.

186. Holdaas H, Fellström B, Jardine AG, et al. Effect of fluvastatin on cardiac outcomes in renal transplant recipients: a multicentre, randomised, placebo-controlled trial. Lancet. 2003;361(9374):2024-2031.

187. Keech A, Colquhoun D, Best J, et al. Secondary prevention of cardiovascular events with long-term pravastatin in patients with diabetes or impaired fasting glucose: results from the LIPID trial. Diabetes Care. 2003;26(10):2713-2721.

188. Pederson TR, Kjekshus J, Pyorala K, et al. Effect of simvastatin on ischaemic signs and symptoms in the Scandinavian simvastatin survival study (4S). Am J Cardiol. 1998;81(3):333-335.

189. Koskinen P, Manttari M, Manninen V, Huttunen JK, Heinonen OP, Frick MH. Coronary heart disease incidence in NIDDM patients in the Helsinki Heart Study. Diabetes Care. 1992;15(7):820-825.

190. Rubins HB, Robins SJ, Collins D, et al; VA-HIT Study Group. Diabetes, plasma insulin, and cardiovascular disease subgroup analysis from the Department of Veterans Affairs high-density lipoprotein intervention trial (VA-HIT). Arch Intern Med. 2002;162(22):2597-2604.

191. Robins SJ, Collins D, Wittes JT, et al; VA-HIT Study Group. Veterans Affairs high-density lipoprotein intervention trial. Relation of gemfibrozil treatment and lipid levels with major coronary events: VA-HIT: a randomized controlled trial. JAMA. 2001;285(12): $1585-1591$.

192. Keech A, Simes RJ, Barter P, et al. Effects of long-term fenofibrate therapy on cardiovascular events in 9795 people with type 2 diabetes mellitus (the FIELD study): randomised controlled trial. Lancet. 2005; 366(9500):1849-1861.

193. Scott R, O'Brien R, Fulcher G, et al. Effects of fenofibrate treatment on cardiovascular disease risk in 9,795 individuals with type 2 diabetes and various components of the metabolic syndrome: the Fenofibrate Intervention and Event Lowering in Diabetes (FIELD) study. Diabetes Care. 2009;32(3):493-498.

194. The ACCORD Study Group. Effects of combination lipid therapy in type 2 diabetes mellitus. N Engl J Med. 2010;362(17):1563-1574.

195. Pignone M, Alberts MJ, Colwell JA, et al. Aspirin for primary prevention of cardiovascular events in people with diabetes. $\mathrm{J} \mathrm{Am} \mathrm{Coll}$ Cardiol. 2010;55(25):2878-2886.

196. Buse JB, Ginsberg HN, Bakris GL, et al; American Heart Association; American Diabetes Association. Primary prevention of cardiovascular diseases in people with diabetes mellitus: a scientific statement from the American Heart Association and the American Diabetes Association. Circulation. 2007;115(1):114-126.

197. Rydén L, Standl E, Bartnik M, et al. Guidelines on diabetes, pre-diabetes, and cardiovascular diseases: executive summary. The Task Force on Diabetes and cardiovascular Diseases of the European Society of Cardiology (ESC) and of the European Association for the Study of Diabetes (EASD). Eur Heart J. 2007;28(1):88-136.

198. Belch J, MacCuish A, Campbell I, et al. The prevention of progression of arterial disease and diabetes (POPADAD) trial: factorial randomised placebo controlled trial of aspirin and antioxidants in patients with diabetes and asymptomatic peripheral arterial disease. $B M J$. 2008;337:a1840. 
199. Ogawa H, Nakayama M, Morimoto T, et al; Japanese Primary Prevention of Atherosclerosis With Aspirin for Diabetes (JPAD) Trial Investigators. Low-dose aspirin for primary prevention of atherosclerotic events in patients with type 2 diabetes: a randomized controlled trial. JAMA. 2008;300(18):2134-2141.

200. De Berardis G, Sacco M, Strippoli GF, et al. Aspirin for primary prevention of cardiovascular events in people with diabetes: meta-analysis of randomised controlled trials. BMJ. 2009;339: b4531.

201. Ridker PM, Cook NR, Lee IM, et al. A randomized trial of low-dose aspirin in the primary prevention of cardiovascular disease in women. N Engl J Med. 2005;352(13):1293-1304.

202. Steering Committee of the Physicians' Health Study Research Group. Final report on the aspirin component of the ongoing Physicians' Health Study. N Engl J Med. 1989;321(3):129-135.

203. ETDRS Investigators. Aspirin effects on mortality and morbidity in patients with diabetes mellitus. Early Treatment Diabetic Retinopathy Study report 14. JAMA. 1992;268(10):1292-1300.

204. Sacco M, Pellegrini F, Roncaglioni MC, Avanzini F, Tognoni G, Nicolucci A; PPP Collaborative Group. Primary prevention of cardiovascular events with low-dose aspirin and vitamin E in type 2 diabetic patients: results of the Primary Prevention Project (PPP) trial. Diabetes Care. 2003;26(12):3264-3272.

205. CAPRIE Steering Committee. A randomized, blinded trial of clopidogrel versus aspirin in patients at risk of ischemic events (CAPRIE). Lancet. 1996;348(9038):1329-1339.

206. Bhatt DL, Marso SP, Hirsch AT, et al. Amplified benefit of clopidogrel versus aspirin in patients with diabetes mellitus. Am J Cardiol. 2002; 90(6):625-628.

207. Platelet Receptor Inhibition in Ischemic Syndrome Management (PRISM) Study Investigators. A comparison of aspirin plus tirofiban with aspirin plus heparin for unstable angina. N Engl J Med. 1998; 338(21):1498-1505.
208. Platelet Receptor Inhibition in Ischemic Syndrome Management in Patients Limited by Unstable Signs and Symptoms (PRISM-PLUS) Study Investigators. Inhibition of the platelet glycoprotein IIb/IIIa receptor with tirofiban in unstable angina and non-Q-wave myocardial infarction. N Engl J Med. 1998;338(21):1488-1497.

209. The PARAGON Investigators. International, randomized, controlled trial of lamifiban (a platelet glycoprotein IIb/IIIa inhibitor), heparin, or both in unstable angina. Platelet IIb/IIIa Antagonism for the Reduction of Acute coronary syndrome events in a Global Organization Network. Circulation. 1998;97(24):2386-2395.

210. Moliterno DJ. Patient-specific dosing of IIb/IIIa antagonists during acute coronary syndromes: rationale and design of the PARAGON B study. The PARAGON B International Steering Committee. Am Heart J. 2000;139(4):563-566.

211. The PURSUIT Trial Investigators. Inhibition of platelet glycoprotein IIb/IIIa with eptifibatide in patients with acute coronary syndromes. Platelet Glycoprotein IIb/IIIa in Unstable Angina: Receptor Suppression Using Integrilin Therapy. N Engl J Med. 1998;339(7): 436-443.

212. Simoons ML; GUSTO IV-ACS Investigators. Effect of glycoprotein $\mathrm{IIb} / \mathrm{III}$ a receptor blocker abciximab on outcome in patients with acute coronary syndromes without early coronary revascularisation: the GUSTO IV-ACS randomised trial. Lancet. 2001;357(9272): 1915-1924.

213. Roffi M, Chew DP, Mukherjee D, et al. Platelet glycoprotein IIb/IIIa inhibitors reduce mortality in diabetic patients with non-ST-segment elevation acute coronary syndromes. Circulation. 2001;104(23): 2767-2771.

214. Theroux P, Alexander J Jr, Pharand C, et al. Glycoprotein IIb/IIIa receptor blockade improves outcomes in diabetic patients presenting with unstable angina/non-ST-elevation myocardial infarction: results from the Platelet Inhibition in Ischemic Syndrome Management in Patients Limited by Unstable Signs and Symptoms (PRISM-PLUS) study. Circulation. 2001;102(20):2466-2472.
Research and Reports in Endocrine Disorders

\section{Publish your work in this journal}

Research and Reports in Endocrine Disorders is an international, peerreviewed, open access journal publishing original research, reports, reviews and commentaries on all areas of endocrinology, endocrine disorders and therapeutic interventions. The manuscript management system is completely online and includes a very quick and fair

\section{Dovepress}

peer-review system. Visit http://www.dovepress.com/testimonials.php to read real quotes from published authors. 